\title{
NEGERI SEJAHTERA ALA KONFUSIANISME MELALUI SELF CULTIVATION
}

\author{
Fachroer Rozie \\ STAI Al-Ghazali Cilacap \\ fakhroer-rozie@yahoo.com
}

\begin{abstract}
Abstrak
Dalam peta keagamaan di Indonesia, ada kecenderungan orang mengidentifikasi Konfusianisme hanya kepada filsafat Konfusius. Masalah mis-konsepsi semacam ini bukan saja pada suatu sisi akan menghambat sebagian orang untuk dapat memahami Konfusius secara komprehensif, pada sisi yang lain ia juga dapat mendistorsi nilai-nilai positif Konfusius dan menafikannya dalam proses pembangunan bangsa. Tulisan ini mengkaji ajaran Konfusianisme, baik sebagai agama maupun sebagai aliran filsafat. Sesungguhnya di dalam ajaran tersebut terkandung kearifan yang bisa dijadikan sebagai pertimbangan dalam mewujudkan bangsa Indonesia yang adil dan makmur. Konfusianisme berangkat dari pemahaman antropocentris, di mana manusia menjadi pusat alam semesta; manusia tidak bisa hidup sendiri, ia mesti berhubungan dengan manusia lain. Oleh karena itu, etika merupakan starting point untuk mencapai kebahagiaan sejati manusia tersebut. Dengan memposisikan manusia sebagai pusat pemikiran, Konfusianisme mengembangkan lima ajaran pokok yang harus ditempuh dalam mencapai kebahagiaan, ketentraman, dan kesejahteraan. Lima ajaran pokok tersebut pada gilirannya harus diimplementasikan dalam kehidupan nyata dalam bentuk etika, baik individual maupun sosial.
\end{abstract}

Abstract

PROSPEROUS COUNTRY ALA CONFUCIANISM THROUGH SELF CULTIVATION. In the religious life of Indonesia, people tend to identify Confucianism only from the philosophy of Confucius. Such a misconception, on the one hand, will not only hinder people to be able to understand Confucius comprehensively, but, on the other hand, it also may distort the positive values of Confucius and exclude them in the process of 
nation building. This work examines the teachings of Confucianism, both as a religion and a philosophical school. In fact, the teachings contains the wisdom that can be used to achieve an equity and prosperity of Indonesia. Confucianism departs from anthropocentric understandings, in which man becomes the center of the universe; man can not live alone and must relate to other human beings. Thus, in Confucianism, ethics is the starting point for achieving the true happiness of man. By positioning the human as the center of thought, Confucianism develops five basic teachings that must be taken in the pursuit of happiness, peace, and prosperity. The Five basic teachings must be implemented in the real life and become intangible ethics, both individually and socially..

Kata Kunci: Konfusianisme; chun tzu; self cultifation; zong.

\section{A. Pendahuluan}

Konfusianisme adalah salah satu aliran pemikiran terbesar di China yang meliputi seluruh ajaran ru jiao jauh sebelum Konfusius lahir hingga dikembangkan oleh Konfusius. Ada sementara anggapan yang mengatakan bahwa Konfusianime merupakan sempalan dari Budha. Anggapan ini keliru dan kekeliruan anggapan ini cukup mendasar, karena Konfusius menurut catatan yang ada hidup pada tahun 551-479 sebelum masehi, sehingga ia lebih tua dari Budha. Lagi pula sebetulnya Konfusius bukan penganjur atau peletak dasar yang pertama dari ajaran Konfusianisme. Beliau adalah penerus dan pengembang yang paling dihormati. Sementara Konfusianisme itu sendiri atau dikenal juga sebagai agama Khonghucu lahir jauh sebelum Konfusius dilahirkan ke dunia. ${ }^{1}$

Dalam peta keagamaan -khususnya di Indnesia, ada kecenderungan orang yang mengidentifikasi Konfusianisme hanya kepada filsafat Konfusius. Ini menjadi problem, karena jelas merupakan mis-konsepsi yang dapat merintangi pemahaman yang lebih dalam dan utuh tentang khazanah dan kompleksitas di dalam Konfusianisme. Citra semacam ini dikembangkan di Indonesia oleh rezim penguasa pemerintahan beberapa waktu lalu melalui Instruksi Presiden No. 14 tahun 1967 dalam kerangka pembauran antara masyarakat China dan pribumi. Dampak dari Instruksi

${ }^{1}$ Lihat Chandra Setiawan, Etika dan Keimanan Khong $\mathrm{Hu} \mathrm{Cu,} \mathrm{(Surabaya:}$ Litbang Majelis Agama Khonghucu Indonesia, 1996), h. 248 
Presiden No. 14 tahun 1967 adalah terjadinya pendangkalan makna Konfusianisme hanya sebagai sebuah aliran filsafat, bukan agama. Penganut agama Khonghucu dipaksa melebur ke dalam agama lain, Budha atau Kristen, bahkan Islam. Menarik jadinya, sebuah contoh seorang pengajar agama Khonghucu di perguruan tinggi cukup ternama, agama di dalam KTP-nya adalah Islam.

Pada era pemerintahan presiden KH. Abdurrahman Wahid, tepatnya pada tahun 2000, Instruksi Presiden (Inpres) No. 14 tahun 1967 dicabut, dan sejak itu di Indonesia kehidupan Konfusianisme semakin semarak, paling tidak terlihat dari tampilan kesenian khas China, Barongsai di semua penjuru kota. Sejak saat itu, umat Khonghucu mulai merasakan kebebasan dalam melaksanakan ajarannya dan mengungkapkan ekspresi-ekpsresi religiusitasnya. sejalan dengan empati besar yang ditunjukkan oleh Gus Dur kepada umat ini jauh sebelum beliau menjadi presiden. Paling tidak Gus Dur telah meletakkan landasan akan pentingnya kesadaran bersama dalam sebuah kehidupan yang plural. Tidak mengherankan jika KH. Abdurrahman Wahid sering disebut sebagai Bapak Etnis Tionghoa. Ketua Klentheng Lam Tjeng Kiong Cilacap (Agus Suyono/Djiauw Yen Hien) juga menyebut dengan pernyataan lugasnya, boleh saja orang menyebut Gus Dur sebagai Bapak Pluralisme, tetapi bagi kami, Gus Dur adalah Bapak Etnis Tionghoa. ${ }^{2}$

Oleh karena itu, Konfusianisme harus dipahami baik sebagai agama maupun filsafat. Menurut Thomas Hosuck Kang, Konfusianisme adalah Humanisme, sebuah filsafat atau sikap yang menyangkut keberadaan manusia, prestasi dan perhatiannya yang agak lebih kepada keberadaan abstrak dan problem-problem teologi. Secara umum dikatakan bahwa Konfusianisme adalah kebudayaan yang berlaku di zona kebudayaan yang terdiri dari China, Jepang, Korea, Taiwan, Hong Kong, Singapore, dan Vietnam. ${ }^{3}$ Oleh karena itu, tulisan ini berusaha mengupas secara ringkas tentang Konfusianisme dan ajaran pokoknya.

\footnotetext{
${ }^{2}$ Agus Suyono, Wawancara, di Cilacap Tanggal 24-08-2010.

${ }^{3}$ Thomas Hosuck Kang, Confucius and Confucianism: Questions and Answers, (Washington, D.C : Confucian Publications, 1997), h. 41-42.
} 


\section{B. Sejarah Lahirnya Konfusianisme}

Konfusianisme lahir dari ajaran Konfusius. Namun biografi lengkap mengenai Konfusius agak sulit didapatkan. Beberapa buku yang cukup mewakili, seperti yang ditulis oleh Cheng Mo To dan kawan-kawan dan dipublikasikan oleh Educational Publications Bureao Pte Ltd di Singapore, berjudul Confucian Ethics Textbook Secondary Three dan Confucian Ethics Textbook Secondary Four. Kendati tidak selengkap yang diharapkan, buku yang dimaksudkan sebagai textbook oleh tim yang dibentuk khusus untuk itu, paling tidak memberikan gambaran yang cukup baik. Ada lagi sebuah buku cukup tebal, An Introduction to Confucianism yang ditulis oleh Xinzhong Yao juga cukup memberikan gambaran.

Konfusius dalam tradisi kebudayaan China sering disebut sebagai the First Teacher (guru pertama). Dalam tradisi filsafat Islam yang disebut guru pertama (al-mualim al-awal) adalah Aristoteles sedangkan guru kedua (al-mualim al-tsani) adalah al-Farabi. Makna the First Teacher di dalam tradisi Konfusianisme bukan berarti tidak ada guru sebelumnya, tetapi karena beliaulah yang menduduki ranking pertama di antara guru-guru yang lain sebelumnya. Konfusius sebetulnya hanya mengembangkan ajaran-ajaran yang sudah ada sebelumnya.

Jika dirunut sejarahnya, peletak dasar Konfusianisme adalah Raja Zhou (kadang ditulis Chou). Periode Zhou ini dikenal sebagai saat berkembangnya kesatuan, kedamaian, dan keadilan di bawah kekuasaan dan kepemimpinan pemerintah pusat. Sistem feodal bekerja sangat baik karena rakyat mematuhi Raja dan sangat kooperatif di antara mereka. Lebih dari itu, rakyat mempunyai sebuah sistem terperinci yang disebut $l i$ (rites) sebagai norma sosial, konvensi, dan hukum-hukum etik dan upacara. Mereka juga mempunyai musik dan tarian indah yang mempengaruhi rakyat untuk hidup secara moral. Setiap orang mengikuti aturanaturan sistem budaya sehingga muncul harmoni dan tatanan sosial yang kemudian disebut sebagai the great harmony. Kondisi ini diidealisasikan oleh Konfusius sebagai masa keemasan (golden age) kekuasaan Zhou yang selalu dijadikan sebagai teladan dan referensi. ${ }^{4}$

${ }^{4}$ Paul Cheng Mo To, (et all.), Confucian Ethics, Textbook Secondary Three, 
Adapun Konfusius sendiri lahir jauh sesudah zaman raja Chou berkuasa. Ia lahir di Ch'u-fu yang terletak di negara Lu (sekarang propinsi Shantung) dan hidup ketika tatanan kehidupan sosial dan politik dalam keadaan kacau dan tidak menentu di akhir zaman kekuasaan Dinasti Zhou. Nama keluarganya adalah K'ung dan namanya sendiri adalah Ch'iu. Tetapi dia dipanggil K'ung Tzu atau K'ung Fu-tzu (Guru Kung).

Kapan Konfusius lahir, tidak ada keterangan yang pasti, kecuali tahun lahirnya yang diyakini valid dan semua pakar bersepakat, yakni tahun 551 sebelum masehi. Namun ada yang mengatakan bahwa hari lahir Konfusius adalah pada tanggal 28 September, dan Konfusius hidup antara tahun 551-479 SM. Menurut penuturan Fung Yu - Lan, pada masa mudanya Konfusius adalah orang yang miskin, namun menjadi pegawai pemerintahan di negara $\mathrm{Lu}$ dan menjelang berusia 50 tahun beliau memperoleh kedudukan resmi yang tinggi. Tetapi sebagai akibat dari konspirasi politik Konfusius terpaksa melepaskan jabatannya dan hidup dalam pembuangan. Selama 13 tahun berikutnya ia mengembara dari negara satu ke negara lainnya dengan selalu berharap memperoleh kesempatan untuk mewujudkan cita-citanya mengadakan perombakan di bidang politik dan kemasyarakatan. Sayang, nyaris di mana-mana ia tidak berhasil, dan akhirnya sebagai orang tua ia kembali lagi ke negara Lu dan di sinilah 3 tahun kemudian ia meninggal pada tahun 479 SM. Konfusianisme kemudian diajarkan dan dikembangkan oleh para penerusnya. ${ }^{5}$

Konfusius memimpikan dapat memposisikan diri seperti Zhou dengan meletakkan ide-ide politiknya, pemerintahan yang humanis (jen-cheng) yang dipelajarinya dari tradisi Zhou ke dalam praksis kehidupan. Bagi Konfusius yang terpenting adalah bagaimana belajar menjadi manusia. Oleh karena itu kabajikan (ren) kemanusiaan) baik sebagai kualitas personal maupun sebagai syarat suatu kepemimpinan adalah esensial bagi martabat individual, solidaritas komunal, dan tatanan politik. Meskipun Konfusius tidak pernah memperoleh kesempatan untuk meletakkan ide-ide

(Singapore: Educational Publications Bureau Pte Ltd, 1985), h. 9 - 10.

${ }^{5}$ Fung Yu-Lan, The Spirit of Chinese Philosophy, terj. E.R. Hughes, (London: Princenton University, 1990), h. 48 
politiknya ke dalam praksis kehidupan bermasyarakat, berbangsa, dan bernegara, namun konsepsi politiknya menjadi karakteristik utama dalam kebudayaan politik di Asia Timur.

Dalam Konfusianisme, manusia adalah pusat alam semesta; manusia tidak dapat hidup sendiri, ia mesti harus berhubungan dengan manusia yang lain. Bagi hidup manusia, tujuan utamanya adalah kebahagiaan individual tanpa rasa takut dari ancaman. Konfusianisme adalah warisan Timur yang unsur-unsurnya menentukan perilaku manusia yang lahir dan besar di bawah pengaruh budaya Confusian dengan tekanan pada kehidupan keluarga dan pengembangan personal. Oleh karena itu, kebudayaan Konfusianisme adalah unsur esensial bagi Asia Timur sebagaimana Kristianitas yang merupakan komponen esensial perilaku masyarakat di Barat.

\section{Ajaran Dasar Konfusianisme}

Untuk mengetahui ajaran-ajaran Konfusianisme, maka tidak ada jalan lain kecuali harus mempelajari kitab-kitab yang memuat ajaran Konfusianisme yang oleh para pengikutnya diyakini sebagai kitab suci. Kitab-kitab yang memuat ajaran-ajaran Konfusius adalah kitab Shi Shu/Su Si (kitab Yang Empat), kitab Xiao (kitab Bakti), kitab Wu Jing (kitab Yang Lima), kitab Analects, kitab Perubahan, kitab Nyanyian, dan lain-lain. Hampir seluruh ajaran Konfusianisme tidak ada yang lepas dari Etika. Dalam kitab Su Si dan Hau King terutama, Konfusius sangat menekankan nilai-nilai etika dalam kehidupan, baik dalam keluarga, masyarakat, maupun dalam kehidupan berbangsa dan bernegara. Etika menentukan bagaimana patutnya manusia hidup dalam masyarakat, yang berarti dalam setiap kegiatan diperlukan kesepakatan bersama agar tidak timbul konflik yang tidak menyenangkan bagi kedua belah pihak. ${ }^{6}$

Di dalam Konfusianisme, etika merupakan entry point untuk mencapai kebahagiaan sejati, dan ini harus dimulai dari hal-hal yang lebih kecil dulu. Jadi, untuk mewujudkan perdamaian dunia, harus dimulai dari diri sendiri, keluarga, masyarakat, baru kemudian negara dan dunia. Dalam kitab Da Xue (Ajaran Besar) I

${ }^{6}$ Wastu Pragantha Chong, Etika Konfusius dan Akhir Abad Ke-20, (Jakarta: Matakin, 1991), h. 1. 
ayat 3-6 Konfusius berkata:

"Tiap benda mempunyai pangkal dan ujung, dan tiap perkara itu mempunyai awal dan akhir. Orang yang mengetahui mana yang dahulu (pertama) dan mana yang kemudian, ia sudah dekat dengan Jalan Suci. Orang zaman dulu yang hendak menggemilangkan Kebajikan Yang Bercahaya pada tiap umat di dunia itu, ia terlebih dahulu berusaha mengatur negerinya; untukmengaturnegerinya,ia(harus)lebih dahulumembereskan rumah tangganya; untuk membereskan rumah tangganya, ia (harus) lebih dulu membina dirinya; untuk membina dirinya, ia (harus) lebih dulu meluruskan hatinya; untuk meluruskan hatinya, ia (harus) lebih dulu mengimankan tekadnya; untuk mengimankan tekadnya, ia (harus) lebih dulu mencukupkan pengetahuannya; dan untuk mencukupkan pengetahuannya, ia (harus) meneliti hakikat tiap perkara. Dengan meneliti hakikat tiap perkara maka cukuplah pengetahuannya; dengan cukup pengetahuannya akan dapat mengimankan tekadnya, dengan tekad yang beriman akan dapat meluruskan hatinya; dengan hati yang lurus (ia) akan dapat membina dirinya; dengan diri terbina (ia) akan dapat membereskan rumah tangganya; dengan rumah tangga yang beres (ia) akan dapat mengatur negerinya; dan dengan negeri yang teratur akan dapat dicapai dunia yang damai. Karena itu dari raja sampai rakyat jelata mempunyai satu kewajiban yang sama yaitu mengutamakan pembinaan diri sebagai pokok (pangkal)"?

Dengan demikian, bagi Konfusianisme pembinaan diri (self cultifation) merupakan pangkal paling utama dalam upaya mewujudkan keadilan dan perdamaian dunia. Model etika ini berbeda dengan Etika Barat yang didasarkan hanya pada keberadaan manusia secara personal dan individual. Etika Konfusianisme didasarkan pada keberadaan manusia di dalam komunitas dan masyarakat yang tak dapat dipisahkan. Integrasi seseorang dengan masyarakat menjadi titik tekan etika Konfusianisme. Thomas Hosuck Kang mengatakan:

"When we look at him from ethics his ethics is based on a relation system, or a concept of belonging: Human being to human being; human being to family; human being to community; human being to society; human being to the state, and human being to the world,

${ }^{7}$ Khong Fu Cu, Kitab Suci Khong Fu Cu Su Si, (Jakarta: Sasana,1997), h. 5-6. 
human being to the universe. Confucius was, in a sense, the father of Oriental ethics, Oriental philosophy, Oriental sociology, Oriental anthropology, and many other fields. In contrast with Western ethics is based on personal and individual human beings who are only related to God, Confucian ethics is based on human beings in the community and society. Without community and society, human beings cannot exist. Without relationships, human beings are not human beings". ${ }^{8}$

Secara lebih khusus, ajaran-ajaran dasar Konfusianisme dapat dikatakan terpusat di sekitar 5 topik utama, yakni ren (humanity/ kemanusiaan), xiao (filial piety/bakti), zhi (wisdom/ kebijakasanaan), yi (righteousness/kebenaran), dan li (propriety/ sopan santun). Ajaranajaran yang lain seperti loyalty (kesetiaan) merupakan derivasi dari kelima ajaran pokok ini.

Dalam kitab Lun Yu XIV: 28 Nabi (Konfusius) bersabda, "Ada tiga hal di dalam Jalan Suci seorang Kuncu yang belum dapat Ku-capai. Penuh Cinta Kasih sehingga tidak merasa susah payah. Bijaksana sehingga tidak dilamun bimbang, dan Berani sehingga tidak dirundung kecemasan". ${ }^{9}$ Tiga hal ini dalam tradisi Konfusianisme sering disebut sebagai tiga pilar kebajikan Konfusius. Kadang disebut pula sebagai "Tri Pusaka". Tri Pusaka dianggap sebagai bekal paling ampuh dalam menghadapi kehidupan dengan segala problematikanya. Dengan cinta kasih, manusia mendapatkan landasan bagi motif perbuatannya, bahwa segala langkah perbuatannya tidak boleh meninggalkan kemanusiaannya sebagai makhluk ciptaan Tuhan yang berakal budi; dengan kebijaksanaan, manusia mampu menangani dan memecahkan segala persoalan secara tepat dan harmonis; dan dengan keberanian, manusia mendapat semangat dan ketahanan dalam menghadapi tantangan maupun dalam meraih cita-cita. Atas dasar ini, Tri Pusaka wajib menjadi tri-tunggal dalam diri setiap penganut Konfusianisme.

Uraian mengenai kelima ajaran pokok di atas adalah sebagai berikut:

\section{Ren (Humanity)}

Ren atau jin dalam bahasa hokian merupakan pusat esensi dalam humanisme Konfusian dan merupakan kebajikan tertinggi.

${ }^{8}$ Thomas Hosuck Kang, Confucius and..., h. 109.

${ }^{9}$ Kong Fu Cu, Kitab Suci...,h. 114. 
Ren sering diterjemahkan sebagai humanity (kemanusiaan), benevolence (cinta), keluhuran budi, kebajikan sempurna, peri cinta kasih, kebaikan, dan berhati manusiawi. Menurut Thomas Hosuck Kang, di dalam Analects, kata ren muncul 108 kali dalam arti yang berbeda, namun memiliki satu esensi yang simpel, yakni kemanusiaan, yang membuat manusia sungguh-sungguh seorang manusia, bukan yang lain. ${ }^{10}$ Oleh karena itu, untuk menemukan ren manusia secara konsisten harus membina hati dan pikirannya (self-cultivation). Ren dapat ditemukan dalam hubungan antara orang tua dan anak dan dalam semua hubungan kemanusiaan di semua tingkatan. Dalam pandangan Konfusius, ren merupakan intisari dari kesempurnaan adi-kodrati, yang diakuinya sendiri belum pernah terwujud sepenuhnya. Dengan mencakup kemampuan manusiawi yang terbaik, ren merupakan suatu kebajikan yang sedemikian tingginya, sehingga untuk membicarakannya harus dilakukan dengan hati-hati. Ren juga digambarkan sebagai sesuatu yang lebih penting dari kehidupan itu sendiri. ${ }^{11}$

Ren dalam pengertian dengan berbagai kualitas seperti di atas tidak dapat berdiri sendiri, tetapi harus selalu terkait dengan hubungan kemanusiaan yang lain. Raymond Dawson menuturkan bahwa pada dasarnya, ren berarti manifestasi dari sifat dasar manusia yang ideal; dan karena etika Khong $\mathrm{Hu} \mathrm{Cu}$ tidak banyak membicarakan kualitas jiwa dan hati dibandingkan dengan aktifitas dan tidak banyak memperhatikan orang secara terpisah daripada orang dalam hubungannya dengan umat manusia lainnya; sehingga kebajikan manusia merupakan kebajikan sosial yang ditempatkan dalam perilaku hubungan antar manusia, maka ren dapat didefinisikan sebagai tatanan hubungan antar umat manusia yang ideal. ${ }^{12}$

Tujuan hidup manusia dalam konsep Konfusianisme adalah mencapai chun tzu (manusia sempurna/insan kamil/gentleman). Derajat manusia chun tzu hanya dapat dicapai jika ia mengamalkan ren dalam kehidupan sosial kemasyarakatan. Oleh karena itu, pencapaian

\footnotetext{
${ }^{10}$ ThomasHosuck Kang, Confucius and..., h. 117.

${ }^{11}$ M. Iksan Tanggok, Jalan Keselamatan Khonghucu, (Jakarta: Gramedia, 2000), h. 69 .

${ }^{12}$ Raymond Dawson, Petuah Konghucu, (Jakarta: Gramedia, 1999), h. 58.
} 
kesempurnaan tidak mungkin berlangsung di luar masyarakat, sebab kesempurnaan itu termanifestasi dalam hubungannya dengan masyarakat. Menurut Fung Yu-lan, hakikat formal kewajiban manusia di dalam masyarakat adalah 'perbuatan yang seharusnya dilakukan', karena segala kewajibannya ialah apa yang seharusnya dilakukan. Tetapi hakikat material kewajiban ini ialah mencintai orang lain. Itulah yang dinamai ren atau kemanusiaan. Seorang bapak berbuat sesuai dengan apa yang seharusnya dilakukan sebagai seorang bapak, seperti misalnya mengasihi anak-anaknya. Begitu pula anak semestinya berbuat sesuai dengan fungsinya sebagai seorang anak yang dapat mengasihi bapaknya. ${ }^{13}$

Menurut Chandra Setiawan, tujuan hidup manusia di dunia ini dalam ajaran Khonghucu adalah mengabdi kepada Tuhan dalam rangka menciptakan dunia yang damai penuh keharmonisan dengan senantiasa membina diri (self-cultivation). ${ }^{14}$ Apa yang dikatakan Chandra Setiawan sesuai dengan ajaran Konfusius dalam Zhong Yong (Tengah Sempurna) XIX: 7 : "Maka seorang Kuncu tidak boleh tidak membina diri; bila berhasrat membina diri, tidak boleh tidak mengabdi kepada orang tua; bila berhasrat mengabdi kepada orang tua, tidak boleh tidak mengenal manusia; dan bila berhasrat mengenal manusia, tidak boleh tidak mengenal kepada Thian (Tuhan Yang Maha Esa)". ${ }^{15}$

Manusia chun tzu adalah manusia yang beriman kepada Tuhan dan telah sempurna pembinaan dirinya sebagai modal untuk mengatur rumah tangga, masyarakat, negara, dan juga dunia, sehingga dapat dicapai dunia yang damai. Ren tergelar di semesta alam. Disebutkan dalam Lun Yu IV: 17, bahwa Nabi Bersabda, "Bila melihat seorang yang Bijaksana, berusahalah menyamainya, dan bila melihat seorang yang tidak Bijaksana, periksalah dirimu sendiri”.

Konfusius dalam Lun Yu VI: 30 menjelaskan, "Seorang yang berperi Cinta Kasih ingin dapat tegak, maka berusaha agar orang lainpun tegak; ia ingin maju, maka berusaha agar orang lainpun

\footnotetext{
${ }^{13}$ Fung Yu-Lan, The Spirit ..., h. 54.

${ }^{14}$ Candra Setiawan, Kehadiran Agama Konghucu di Indonesia, (Jakarta: Matakin,
} 2000), h. 60.

${ }^{15}$ Khong Fu cu, Kitab Bakti(Hau King), (Jakarta: Matakin, 1999), h. 82 
maju”. Yang dapat memperlakukan orang lain dengan contoh yang dekat (diri sendiri), sudah cukup untuk dinamakan seorang yang berperi Cinta Kasih". Jadi kerjasama adalah jalan menuju kemajuan, tentu sesuai bidangnya masing-masing. Konfusianisme tak membenarkan mencari posisi dengan cara menjilat atasan, menyikut sejawat, dan menginjak bawahan.

2. Xiao (Filial Piety)

Xiao artinya bakti anak kepada orang tua. Isinya adalah seorang anak harus berbakti kepada orang tua dan kakak-kakaknya, isteri kepada suami, orang tua memberikan kasih sayang kepada anakanaknya, suami kepada isterinya, kakak kepada adiknya, dan juga saling menghormati antara sesama teman. Ajaran xiao meletakkan landasan bagi etika keluarga. Keluarga yang baik merupakan dasar bagi masyarakat yang baik, dan keluarga yang baik didasarkan pada kasih sayang orang tua kepada anak-anaknya, dan kesetiaan serta kepatuhan anak-anak kepada orang tuanya. Dalam sejarah panjang China Tradisional, ajaran ini sangat mempengaruhi pola politik dan model sosial China. Dalam pandangan Konfusianisme, moralitas adalah bagian yang paling utama dalam setiap langkah kehidupan manusia, termasuk dan terutama dalam hal pengelolaan masyarakat atau negara. ${ }^{16}$ Artinya betapapun tinggi jabatan seseorang, jika hal itu diperoleh dengan cara yang melanggar nilai dan norma agama maka tidak akan ada artinya. Dalam Lun Yu IV: 5.1 disebutkan: "Kekayaan dan kemuliaan adalah keinginan semua orang, bila hal tersebut tidak diperoleh dengan jalan suci, maka jangan laksanakan". ${ }^{17}$ Jelas bahwa Konfusianisme secara tegas melarang semua bentuk korupsi, kolusi, dan nepotisme dengan seluruh turunannya.

Tentang ajaran xiao atau filial piety atau bakti, Lee Chuek-Yin membuat kesimpulan bahwa "Confucius viewed filial piety as not only providing material needs and ritual burial. The practice of filial piety should not be thought of as fulfilling a formality, but should be carried out as a natural and spontaneous product with respect and sincerity". ${ }^{18}$

${ }^{16}$ Budi S. Tanuwibowo, Integrity, Commitment, and Faith (Jogjakarta: Dian Interfidei, 2000), h. 90.

${ }^{17} \mathrm{Kong} \mathrm{Fu} \mathrm{Cu}, \mathrm{Kitab}$ Suci...,h. 245.

${ }^{18}$ Dalam Lee T. Oei, Chu Hsi dan Hidup Beragama Konfuciani, (Jakarta: Matakin, 1997), h. 100. 
Jika laku bakti menjadi perilaku setiap manusia niscaya kedamaian di atas dunia akan terwujud. Tidak diragukan lagi bahwa laku bakti telah menciptakan ikatan emosional yang tinggi sesama warga di dalam keluarga, masyarakat, dan negara yang menganut prinsip-prinsip Konfusianisme seperti di Taiwan. Di Taiwan, etika Konfusianisme menjadi landasan kehidupan bermasyarakat. Pendeknya, dalam bahasa Chandra Setiawan, ajaran moral Konghucu adalah 'Pancasilanya' Taiwan. ${ }^{19}$

\section{Zhi (Wisdom)}

Zhi secara harfiah berarti kebijaksanaan (wisdom), kearifan, atau pengertian. Zhi merupakan salah satu dari Tri Pusaka yang menjadi landasan sikap moral seorang chun tzu. Dialog antara konfusius dan muridnya berikut ini yang diabadikan dalam kitab Lun Yu (Analect) cukup jelas menggambarkan. Bahwa suatu hari, seorang murid Konfusius, Fan Chi berkonsultasi kepada Konfusius. Katanya, "Guru, apa itu kebijakan?” Konfusius menjawab, “yaitu mengenal manusia” (Lun Yu XII: 22). Pada kali yang lain Konfusius berkomentar, "Jangan khawatir orang tidak mengenal dirimu, khawatirlah kalau kau tidak dapat mengenal orang lain" (Lun Yu I: 16). Dalam Lun Yu IV: 17, Nabi bersabda, "Bila melihat seorang yang Bijaksana, berusahalah menyamainya; dan bila melihat seorang yang tidak Bijaksana, periksalah dirimu sendiri”.

Orang bijaksana, kata Konfusius tidak akan dilamun bimbang, sementara yang berperi Cinta Kasih tidak merasakan susah payah, dan yang Berani tidak dirundung ketakutan (Lun Yu IX: 29). Sikap bijaksana juga tercermin dalam ucapan Konfusius dalam Lun Yu XI: 17, bahwa "Bila kau mengetahui sesuatu, katakanlah bahwa kamu tahu, dan bila kamu tidak mengetahui sesuatu, katakanlah bahwa kamu tidak tahu. Itulah pengetahuan sejati”.

Kebijaksanaan juga mencakup pengetahuan tentang yang benar dan yang salah. seorang yang bijak adalah seorang yang mampu menegakkan kebenaran pada saat kapanpun dan di manapun. Seorang yang bijak adalah orang yang mengetahui prinsip-prinsip tentang hidup yang benar dan mampu mengilhami orang lain untuk melakukan hal yang benar. Inilah esensi kebijakan Konfusius.

${ }^{19}$ Candra Setiawan, Etika dan Keimanan..., h. 50. 


\section{Yi (Righteousness)}

Konsep mengenai Righteousness atau yi atau kebenaran merupakan konsep dalam ajaran Konfusianismeyang dikembangkan pertama kali oleh Mencius, tokoh kedua setelah Konfusius. Yi dalam ajaran Konfusianisme adalah sikap yang paling pas di kala situasi terjepit. Misalnya pilihan untuk mempertahankan kebenaran kendati karena itu harus mati adalah suatu pilihan yang tepat. Untuk dapat melaksanakan ajaran yi diperlukan keberanian (courage), yang tidak lain adalah salah satu dari tiga pilar kebajikan Konfusius. Secara sepintas konsep yi berseberangan dengan konsep ren. Namun sebenarnya justru saling mendukung. Yi menuntut keberanian untuk mengatakan yang benar adalah benar dan yang salah adalah salah tanpa harus meninggalkan humanity dalam hubungan kemanusiaan. Sementara ren menuntut kearifan dan toleransi dalam mengambil sikap, tetapi tetap tegas dalam mengambil jarak antara yang benar dan yang salah. Ketegasan bertindak tidak berarti kehilangan kearifan dan toleransi. Karena kebenaran adalah hukum moral yang harus ditegakkan dan digemilangkan.

Chen Junmin mengatakan bahwa kebenaran moral (yi) meliputitindakanyang benar,yaitu bagaimana seseorang bertingkah laku. ${ }^{20}$ Dalam bentuk asalnya, huruf Cina untuk yi dibentuk dari 'domba' di atas 'saya' yang dibentuk dari 'tangan' dan 'anak panah'. Jadi, gambarannya seperti domba penurut yang menundukkan diri yang lebih agresif dan sangat tepat untuk menerangkan huruf $y i$. Ketika kebenaran ditegakkan, 'diri' tidak akan dinomorsatukan demi moralitas. Oleh karena itu, tidaklah mengherankan bahwa dalam bentuknya yang disederhanakan, komponen 'saya' telah dihilangkan, sehingga huruf itu berisi tiga coretan yang sederhana dan 'seimbang' yang melambangkan sikap keadilan dan kejujuran.

Sementara itu, Thomas Hosuck Kang mengatakan : "The yi exists basically in the relationship between the ruler and subject and the people. The yi can be translated as duty, righteousness, propriety, and loyalty." ${ }^{21}$ Kebenaran moral merupakan salah satu nilai moral yang menekankan padatindakanyang dilakukandemitindakanitu sendiri

${ }^{20}$ Dalam Wang Miaoyang, (ed), Civil Society in Chinese Context, (Washington D.C. USA: The Council For Ressearch in Value \& Philosophy, 1997), h. ix

${ }^{21}$ Thomas Hosuck Kang, Konfucius and..., h.118. 
tanpa menginginkan suatu keuntungan yang bersifat material. Oleh karena itu, pembelaan kepada seseorang tidak diarahkan kepada 'diri', tetapi diarahkan kepada nilai kebenaran yang dibawa oleh 'diri' tersebut. Menurut Konfusius, jika kita mengembangkan kebenaran moral maka kita dapat menyucikan jiwa. Kebenaran, betapapun pahitnya untuk disampaikan, tetaplah kebenaran. Oleh karena itu jika ada pertentangan antara kepentingan pribadi dan kebenaran, maka kebenaranlah yang harus dimenangkan. Untuk menghadapi kenyataan seperti ini, ajaran Konfusianisme, menurut Chandra Setiawan, telah memberikan obat yang dalam hal tertentu dapat mengubah nilai manusia yang mentalnya mengutamakan keuntungan dan selanjutnya membantu membentuk pandangan yang beradab dan sehat bagi nilai-nilai kehidupan. ${ }^{22}$

5. Li (Propriety)

Li dalam bahasa Indonesia sering diterjemahkan sebagai sopan santun, tata krama, dan adab. $L i$ adalah satu prinsipyang harus ditaati oleh manusia dalam menjalin hubungan dengan manusia lain. Sebetulnya dalam arti ini merupakan ekspresi atau ujud dari kemanusiaan dan kebenaran. Sebagai sebuah ritual, upacara, li membantu untuk disiplin diri dan pikiran dalam melakukan sesuatu yang sesuai dengan semua situasi kemanusiaan. Li juga dapat membawa semua anggota keluarga atau komunitas ke dalam suatu sikap khusus seperti dalam upacara pesta, pemakaman, dan hari nasional. Praktek li dapat menyelesaikan perbedaan di antara rakyat di suatu negara dan dapat mengurangi friksi yang muncul dalam hubungan antar sesama. Ini adalah makna li dalam interaksi sosial yang diterima sebagai sebuah kebenaran dan secara nalar dapat diterima oleh semua anggota suatu komunitas.

Menurut Konfusius, konsep tentang li lebih dari sekedar pertanyaan tentang kebiasaan dan tingkah laku. Ia adalah jiwa hidup dan nilai moral. Jiwa hidupnya adalah kemanusiaan (ren) yang merupakan derivasi nilai moral dari hubungannya dengan ren. ${ }^{23}$ Li menentukan sikap seseorang tentang bagaimana sesuatu harus dilakukan sekaligus menempatkan manusia dalam hubungan yang lembut dengan sesama. Konfusius menyatakan bahwa: "By studying

${ }^{22}$ Candra Setiawan, Etika dan ..., h. 101.

${ }^{23}$ Paul Cheng Mo To, Confucian Etic...., h. 36. 
the classics (learning) and thinking about the lessons found there (reflection), anyone can nourish his innate 'moral power' (de). By studying and practicing the rules of propriety (the li), we place ourselves on the path to moral maturity, and gradually become fit to take our place in society". ${ }^{24}$

Ada kekuatan moral yang sangat dahsyat di dalam $l i$ jika ia betul-betul dilaksanakan dalam praktek hidup sehari-hari. Kekuatan itu adalah ketika seseorang memperoleh tempat yang layak di masyarakat. Terjadi transformasi diri ke dalam masyarakat.

\section{Individualitas Dan Sosialitas}

Pembinaan diri (self-cultivation) dalam pandangan Konfusianisme sangat menentukan sikap dan perilaku sosialnya. Dari diri yang bajik dan bijak, masyarakat yang terbangun juga akan bajik dan bijak, aman dan damai. Pada akhirnya negara dan dunia pun akan damai dan sejahtera. Sebelum berbicara tentang pembangunan masyarakat dan negara atau pemerintahan, diri harus dibangun terlebih dahulu. Urut-urutannya sesuai The Great Learning (Ajaran Besar) dimulai dari diri, keluarga, masyarakat, negara/pemerintahan, baru terakhir dunia secara universal. Pembinaan diri pertama-tama dimulai dengan meluruskan hati. Bab-bab dalam Ajaran Besar adalah Meluruskan Hati Membina Diri (Bab VII), Membina Diri Membereskan Rumah Tangga (Bab VIII), Membereskan Rumah Tangga Mengatur Negara (Bab IX), dan Teratur Negara Damai Dunia (Bab X). Pembinaan diri dalam Konfusianisme merupakan salah satu tema besar dan universal. Pembinaan diri menjadi penting karena menurut Konfusianisme, yang ideal bagi setiap manusia adalah menjadi guru, manusia bajik, dan manusia yang tercerahkan melalui pembinaan diri. ${ }^{25}$

Andaian ideal sebagai ultimate goal dari produk pembinaan diri adalah tercapainya harmoni dan keseimbangan (harmony and equilibrium) di antara sesama anggota masyarakat dan bangsa. Pembinaan diri dimulai dengan membersihkan hati, sebab diri yang diliputi geram dan marah tidak dapat berbuat lurus; yang diliputi

${ }^{24}$ Lihat Philip J. Ivanhoe, dalam Lasiyo, Ajaran Konfusianisme, Tinjauan Sejarah dan Filsafat dalam Pergualatn Mencari Jati Diri, (Yogyakarta: Dian Interfidey, 1995), h. 53.

${ }^{25}$ Thomas Hosuck Kang, Confucius and..., h. 60. 
takut dan khawatir tidak dapat berbuat lurus, yang diliputi suka dan gemar tidak dapat berbuat lurus; dan yang diliputi sedih dan sesal tidak dapat berbuat lurus (Ajaran Besar VII: 1).

Dasar dari pembinaan diri terletak pada ren sebagai human nature. Keberadaan manusia secara individual bukanlah substansi individual yang mempunyai eksistensi independen. Keberadaan manusia selalu tak lepas dari keberadaan manusia yang lain. Saling hubungan antara sesama manusia menjadikan manusia disebut sebagai manusia. Manusia menyempurnakan individualitas dan keunikannya melalui hubungan dengan sesama dengan ren sebagai hakikat esensialnya. Lau Kwok-Keung mengatakan:

"Ren as the essential nature of the human being is a potential rather than an actualized form and property. That is to say, Ren is without an unchangeable actualized form. In different situations and different relationships, Ren may be actualized or manifested through different forms of actions and behaviour. Not to tell a lie is a manifestation of Ren, but to tell a lie in order to save a friend's life is also a manifestation of Ren. Be loyal to one's own government is manifestation of Ren, but be loyal to tyranny is against Ren". ${ }^{26}$

Ketika seorang individu melakukan kegiatan, ren menghadapi objek dari hubungan atau situasi yang berbeda, dia akan menunjukkan kebajikan yang berbeda pula. Kebajikan yang berbeda ini merupakan standar moral bagi kegiatan seseorang dalam situasi dan hubungan yang berbeda. Dengan demikian individualitas dan sosialitas adalah dua hal yang saling mengandaikan. Yang disebut pertama menentukan yang kedua, sementara yang disebut kedua mencerminkan substansi yang pertama. Melalui ren yang berkembang dalam hati manusia, maka akan memancar rasa empati manusia dalam berinteraksi dengan sesama.

\section{E. Zhong Sebagai Moralitas Sosial Konfusiani}

Jika filial piety merupakan landasan bagi etika keluarga, maka zhong atau loyalty merupakan akar dari moralitas sosial. Menurut Lee Cheuk-Yin, aplikasi dari kedua konsep tersebut secara kuat memengaruhi formasi dan pola politik serta model sosial

${ }^{26}$ Dalam Silke Krieger \& Ralf Trauzettel (ed), Confucianism and The Modernization of China, (Germany: V. Hase \& Koehler Verlang Mainz, 1991), h. 212. 
tradisional China. ${ }^{27}$ Zhong sering dimaknai dengan kesetiaan/ kejujuran. Di dalam Lun Yu IV: 15, Nabi bersabda, Cham, ketahuilah, Jalan Suci-Ku itu satu, tetapi menembusi semuanya." Tentu saja maksud Konfusius dengan pernyataannya bahwa Jalan Suci-Ku itu satu bukan berarti hanya ada satu prinsip moral yang harus menjadi pegangan, karena Konfusius tidak hanya mengajarkan satu nilai penting saja tentang moralitas. Menurut Cheng Mo To, dkk., apa yang dimaksudkan oleh Konfusius dengan pernyataannya di atas adalah bahwa di dalam praksis kehidupan sehari-hari semua nilai dan prinsip moralnya harus didasarkan pada satu sikap dasar, yaitu satya dan tepa-sarira. ${ }^{28}$

Disebutkan pula di dalam kitab Tengah Sempurna Bab Utama XII (Zhong Yong), bahwa Jalan Suci itu tidak jauh dari manusia. Bila seseorang menganggap Jalan Suci itu hal yang menjauhi manusia, itu bukan Jalan Simpauci. Satya dan tepa-sarira itu tidak jauh dari Jalan Suci. Apa yang tidak diharapkan menimpa diri sendiri, janganlah diberikan atau dilakukan kepada orang lain. Ajaran ini secara vertikal menjalinkan manusia kepada Thian/Tuhan (dalam tradisi Islam disebut hablun min Allah) sebagai al-khalik dan secara horizontal (dalam tradisi Islam disebut hablun min al-nas) menjalinkan manusia kepada sesama dan lingkungannya.

Zhong/loyalty sebagai landasan etika sosial memungkinkan terjadinya harmoni dan keseimbangan yang mapan dalam kehidupan bermasyarakat. Artinya masyarakat yang terbangun adalah masyarakat yang berkeadaban yang memiliki integritas, sebuah masyarakat ideal yang memiliki tingkat kohesi sosial tinggi dalam terminologi Emile Durkheim atau civil society dalam terminologi de' Tocqueville. Model masyarakat seperti ini memiliki kemandirian dan kemerdekaan serta memiliki tingkat partisipasi yang tinggi. Kehidupan yang harmonis menurut Chandra Setiawan, bukanlah kehidupan yang bebas dari kesedihan dan kedukaan, karena pada dasarnya kesedihan, kegembiraan, kedukaan, perbedaan, dan persamaan adalah bagian yang tak terpisahkan dari romantika kehidupan. Kehidupan yang harmonis bukan saja harmoni dengan sesama manusia, tetapi juga harmoni dengan alam, dengan cara

\footnotetext{
${ }^{27}$ Dalam Lee T. Oei, Chu Hsi..., h. 96.

${ }^{28}$ Paul Cheng Mo To, Confucian Etic..., h. 62.
} 
mempertahankan kelestarian alam dan dalam menggali sumbersumber alam senantiasa memperhatikan kelestarian lingkungan. ${ }^{29}$

\section{F. Penutup}

Konfusianisme pada hakekatnya merupakan seluruh ajaran, gagasan, dan pikiran tentang peradaban, tradisi, dan kebudayaan China yang kemudian disebut sebagai agama Khonghucu. Konfusianisme berangkat dari pemahaman antropocentris, di mana manusia menjadi pusat alam semesta; manusia tidak bisa hidup sendiri, ia mesti berhubungan dengan manusia lain. Tujuan hidup manusia adalah mencapai kebahagiaan individual tanpa ada rasa takut dari ancaman. Oleh karena itu, etika merupakan starting point untuk mencapai kebahagiaan sejati manusia tersebut. Adapun jalan untuk mencapai kebahagiaan itu bisa diraih dengan menjalankan lima ajaran pokok konfusianisme, yaitu:ren (humanity/kemanusiaan), xiao (filial piety/bakti), zhi (wisdom/kebijakasanaan), yi (righteousness/ kebenaran), dan $l i$ (propriety/sopan santun). Ajaran-ajaran yang lain seperti loyalty (kesetiaan) merupakan derivasi dari kelima ajaran pokok ini. Kelima ajaran pokok Konfusianisme itu kemudian harus diimplementasikan dalam kehidupan nyata sehingga berwujud etika individual dan etika sosial. Dengan demikian, akan tercapai ketenangan dan kedamaian yang pada akhirnya tercapai kebahagiaan sejati. []

\section{Daftar Pustaka}

Chong, Wastu Pragantha, Etika Konfusius dan Akhir Abad Ke-20, Jakarta: Matakin, 1991.

Dawson, Raymond, Petuah Konghucu, Jakarta: Gramedia, 1999.

Fucu, Khong, Kitab Bakti(Hau King), Jakarta: Matakin, 1999. , Kitab Suci Khong Fu Cu Su Si, Jakarta: Sasana,1997.

Lasiyo, Ajaran Konfusianisme, Tinjauan Sejarah dan Filsafat dalam Pergualatn Mencari Jati Diri, Yogyakarta: Dian Interfidei, 1995.

Kang, Thomas Hosuck, Confucius and Confucianism: Questions and Answers, Washington, D.C : Confucian Publications, 1997.

${ }^{29}$ Candra Setiawan, Ajaran Konghucu...., h. 102. 
Krieger, Silke \& Trauzettel, Ralf(ed), Confucianism and The Modernization of China, Germany: V. Hase \& Koehler Verlang Mainz, 1991.

Miaoyang, Wang, (ed), Civil Society in Chinese Context, Washington D.C. USA: The Council For Ressearch in Value \& Philosophy, 1997.

Oei, Lee T. , Chu Hsi dan Hidup Beragama Konfuciani, Jakarta: Matakin, 1997.

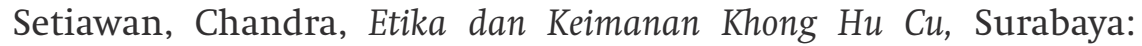
Litbang Majelis Agama Khonghucu Indonesia, 1996. , Kehadiran Agama Konghucu di Indonesia, Jakarta: Matakin, 2000.

Suyono, Agus, Wawancara, di Cilacap Tanggal 24-08-2010.

Tanggok, M. Iksan, Jalan Keselamatan Khonghucu, Jakarta: Gramedia, 2000.

Tanuwibowo, Budi S. , Integrity, Commitment, and Faith, Jogjakarta: Dian Interfidei, 2000.

To, Paul Cheng Mo, (et all.), Confucian Ethics, Textbook Secondary Three, Singapore: Educational Publications Bureau Pte Ltd, 1985.

Yu-Lan, Fung, The Spirit of Chinese Philosophy, terj. E.R. Hughes, London: Princenton University, 1990. 
